\title{
PERTANGGUNG JAWABAN PIHAK KEPOLISIAN DAN UPAYA HUKUM YANG DILAKUKAN TERSANGKA ATAS TERJADINYA SALAH TANGKAP
}

\author{
I Gede Banyu Bagastya Nida, A.A Sagung Laksmi Dewi, I Made Budiyasa \\ Fakultas Hukum Universitas Warmadewa, Denpasar-Bali, Indonesia
}

\begin{abstract}
Abstrak
Sistem peradilan pidana berkewajiban yaitu untuk melakukan pemeriksaan secara detail, lebih mengutamakan bukti serta fakta yang cukup kuat agar menentukan seseorang itu bersalah dalam permasalahan kejahatan, serta mampu melakukan pemidanaan dengan tujuan yang sesuai pidana itu sendiri dan hak-hak yang seharusnya diterima oleh terpidana. Penelitian ini merupakan penelitian hukum normatif, maka fokus penelitian adalah pada penelitian kepustakaan. Adapun tujuan penelitian ini yaitu: mengetahui tanggung jawab pihak kepolisian jika terjadi salah tangkap serta mengetahui upaya hukum yang dapat ditempuh tersangka jika terjadinya salah tangkap. Hasil penelitian menunjukkan bagaimana Penyidik Polri mempertanggungjawabkan jika terjadi penyimpangan dalam menjalankan tugas dan upaya hukum yang dapat dilakukan oleh tersangka jika terjadi penyimpangan oleh Penyidik Polri. Pertama, bentuk sanksi yang terdapat dalam Kode Etik Kepolisian Negara Republik Indonesia jika dilanggar adalah sebagai berikut; a) Perilaku pelanggaran dinyatakan sebagai tindakan tercela; b) Kewajiban pelanggar untuk meminta maaf secara terbatas atau langsung; c) Kewajiban pelanggar untuk mengikuti reinvention profesional; d) Pelanggar dinyatakan tidak berhak lagi menjalankan fungsi Kepolisian, selanjutnya upaya hukum yang dapat dilakukan jika terjadi pelanggaran sesuai Pasal 1 ayat 22 KUHAP, kompensasi. Dasar hukum tuntutan ganti rugi adalah pasal 77 huruf b KUHAP, kemudian rehabilitasi sesuai pasal 1 ayat 10 KUHAP butir c. Dari penelitian ini dapat disimpulkan bahwa bentuk pertanggungjawaban yang dilakukan oleh penyidik Polri terbagi menjadi 2 yaitu pertanggungjawaban materil yaitu sanksi pernyataan pengampunan dan pertanggungjawaban imateril yaitu tentang sanksi berupa kewajiban pemulihan di lembaga pendidikan Polri. Sedangkan upaya hukum yang dapat dilakukan oleh korban salah tangkap adalah dengan mengajukan tuntutan ganti rugi dan rehabilitasi.
\end{abstract}

Kata kunci: Pertanggung jawaban; Upaya Hukum; Salah Tangkap

\begin{abstract}
The criminal justice system is obliged, namely to carry out detailed examinations, prioritize evidence and facts that are strong enough to determine that a person is guilty in criminal matters, and is able to carry out convictions with a purpose that is in accordance with the crime itself and the rights that should be accepted by the convicted person. This research is a normative legal research, so the research focus is on library research. The objectives of this study are: to know the responsibility of the police if there is a wrong arrest and to know the legal remedies that the suspect can take if a wrong arrest occurs. The results of the research show how Police Investigators are held accountable for irregularities in carrying out their duties and legal remedies that can be taken by the suspect in the event of irregularities by the Police Investigator. First, the forms of sanctions contained in the Code of Ethics for the Indonesian National Police if they are violated are as follows; a) Violation behavior is declared as despicable act; b) The offender's obligation to apologize in a limited or direct manner; c) The violator's obligation to follow professional reinvention; d) The offender is declared no longer entitled to carry out the police function, then legal remedies that can be taken if a violation occurs in accordance with Article 1 paragraph 22 of the Criminal Procedure Code, compensation. The legal basis for the claim for compensation is article 77 letter $b$ KUHAP, then rehabilitation according to article 1 paragraph 10 KUHAP point $c$. From this research it can be concluded that the form of accountability carried out by the Police investigators is divided into 2, namely material accountability, namely the sanction of forgiveness and immaterial accountability, namely about sanctions in the form of mandatory recovery at the Polri educational institution. Meanwhile, the legal remedy that can be taken by the victim of a wrongful arrest is to file a claim for compensation and rehabilitation.
\end{abstract}

Keywords: Liability; Legal Efforts; Wrongful Arrest 


\section{PENDAHULUAN}

Yang dimaksud dengan sistem peradilan pidana berkewajiban yaitu untuk melakukan pemeriksaan secara detail, lebih mengutamakan bukti serta fakta yang cukup kuat agar menentukan seseorang itu bersalah dalam permasalahan kejahatan, serta mampu melakukan pemidanaan dengan tujuan yang sesuai pidana itu sendiri dan hak-hak yang seharusnya diterima oleh terpidana (Harahap, 2006). Keharusan ini mutlak adanya kegiatan hukum yang sangat menitikberatkan sesuatu kewenangan di lembaga penegak hukum dibandingkan dengan posisi tersangka, terdakwa, dan oleh terpidana. Maka karena hal ini terjadinya tindak pidana, kepolisian berperan sebagai lembaga pertama yang langsung turun berhadapan dengan masyarakat, baik sebagai korban kejahatan, atau saksi, ataupun tersangka (Lathif, 2018).

Terkait dengan penelitian terdahulu oleh (Tetepa, 2013) menyatakan bahwa bentuk tanggung jawab yang dilakukan oleh penyidik Polri dibedakan menjadi 2 yaitu tanggung jawab materiil, yakni mengenai sanksi pernyataan maaf serta tanggung jawab imateriil yakni mengenai sanksi berupa kewajiban pembinaan ulang di lembaga pendidikan Polri. Sedangkan upaya hukum yang dapat dilakukan oleh korban salah tangkap yaitu dengan melakukan tuntutan ganti rugi dan rehabilitasi.

Hukum di Indonesia tentu saja berkaitan dengan pihak penegak hukumnya, yaitu pihak kepolisian, kepolisian bertindak sebagai pengawas dan sebagai penegak hukum. Kekuatan tersebut ada pada diri manusia dan pada dasarnya tidak terletak pada kemampuan fisik maupun kemampuan jiwanya saja, namun terletak pada kemampuan bekerjasama manusia dengan manusia lainnya. Karena dengan manusia lain, mereka dapat menciptakan kebudayaan dapat membedakan manusia dengan makhluk hidup lain. Yang menyadarkan manusia ada tingkat mutu, harkat dan martabat, sebagai manusia yang hidup pada zaman sekarang atau zaman yang akan datang. Berdasarkan latar belakang yang telah dijelaskan oleh penulis diatas, rumusan masalah yang akan penulis uraikan adalah sebagai berikut: bagaimanakah tanggung jawab pihak kepolisian jika terjadi salah tangkap serta bagaimanakah upaya hukum yang dapat ditempuh tersangka jika terjadinya salah tangkap.

Adapun tujuan penelitian ini yaitu 1) untuk melatih mahasiswa dalam penulisan karya ilmiah. 2) untuk Melakukan pelaksanaan Tri Dharma Perguruan Tinggi salah satunya di bidang penelitian. 3) agar memperoleh gelar sarjana dalam bidang Ilmu Hukum. 4) untuk mengembangkan pribadi mahasiswa dalam kehidupan bermasyarakat. 5) untuk mengetahui dan mengkaji tanggung jawab pihak kepolisian jika terjadi salah tangkap. 6) untuk mengetahui dan mengkaji upaya hukum yang ditempuh tersangka jika terjadi salah tangkap.

\section{METODE PENELITIAN}

Penelitian ini merupakan penelitian hukum normatif yang merupakan salah satu jenis penelitian yang dikenal umum dalam kajian ilmu hukum. Mengingat penelitian ini menggunakan pendekatan normatif yang tidak bermaksud untuk menguji hipotesa, maka titik berat penelitian tertuju pada penelitian kepustakaan. Pengumpulan bahan hukum dilakukan dengan prosedur identifikasi dan inventarisasi hukum positif sebagai suatu kegiatan pendahuluan. Biasanya, pada penelitian hukum normatif yang diteliti hanya bahan pustaka atau data sekunder yang mencakup bahan hukum primer dan sekunder. Sedangkan pendekatan masalah yang digunakan secara yuridis yaitu dengan meninjau peraturan yang berhubungan dengan permasalahan. Serta menggunakan bahan-bahan hukum sesuai dengan undang undang yang berlaku.

\section{HASIL DAN PEMBAHASAN}

\section{Tanggung Jawab Kepolisian Jika Terjadi Salah Tangkap}

Sifat manusia yaitu makhluk bermoral. Namun manusia juga seorang pribadi, serta sebagai makhluk pribadi manusia memiliki pendapat sendiri, perasaan sendiri, keinginan agar berbuat maupun bertindak, suatu barang tentu apabila perbuatan serta tindakan tersebut dihadapan orang banyak, bisa jadi mengundang kekeliruan serta juga kesalahan. Untuk itulah agar manusia itu dalam mengisi kehidupannya yang mempunyai makna, maka dari itu manusia perlu diberi Tanggung Jawab.

Tanggung jawab sama halnya bisa berkaitan dengan kewajiban. Kewajiban merupakan suatu yang dapat dibebankan terhadap seseorang itu sendiri. Kewajiban adalah bandingan terhadap hak dan dapat juga tidak memicu kepada hak (Sudiro, 2012). Maka tanggung jawab dalam hal ini yaitu tanggung jawab menurut kewajibannya (Dyani, 2017). Kewajiban dapat diuraikan menjadi 2 bagian, sebagai berikut : 
1. Kewajiban terbatas

Kewajiban dan tanggung jawab ini diberlakukan kepada setiap orang. Contohnya undangundang akan larangan membunuh, mencuri yang disampingnya dapat diadakan hukumanhukuman lainnya.

2. Kewajiban tak terbatas

Kewajiban ini tanggung jawabnya dapat diberlakukan untuk semua orang. Tanggung jawab terhadap kewajiban ini bernilai lebih tinggi, karena dijalankan oleh suara hati, yaitu seperti keadilan serta kebajikan.

Orang-orang bertanggung jawab bisa memperoleh kebahagiaan, dikarenakan seseorang tersebut dapat menjalankan kewajibannya. Kebahagiaan itu bisa dirasakan oleh dirinya maupun oleh masyarakat lain. Sebaliknya, jika seseorang tidak bertanggung jawab ia akan menghadapi kesulitan dikarena ia tidak mentaati aturan, atau norma, maupun nilai-nilai yang berlaku.

Tanggung jawab ialah suatu keadaan dimana seseorang berkewajiban menanggung segala sesuatunya apabila terjadi apa-apa dapat diajukan penuntutan (Sudjana, 2019). Bertanggung jawab menurut Kamus Umum Bahasa Indonesia adalah berkewajiban untuk menanggung segala suatu akibat oleh perbuatan seorang tersebut yang sengaja maupun yang tidak disengaja sebagai bentuk wujud kesadaran akan kewajiban atas apa yang dibuat, baik perbuatan yang merugikan maupun menyenangkan. Tanggung jawab adalah ciri dari seseorang yang beradab karena seseorang itu mampu merasa bertanggung jawab sehingga seseorang tersebut menyadari baik atau buruknya perbuatan yang ia perbuat tersebut.

Kepolisian adalah pihak penting yang bertugas untuk melindungi Negara dibawah pertanggung-jawaban presiden. Polisi merupakan pranata Negara umum yang merupakan pegawai negri sipil yang menjaga ketertiban, keamanan, dan penegakan hukum diseluruh wilayah Negara Kesatuan Republik Indonesia (NKRI) (Undang-Undang Republik Indonesia Nomor 2 Tahun 2002 Tentang Kepolisian Negara Republik Indonesia, n.d.). Polisi Republik Indonesia (POLRI) dibentuk sejak tanggal 19 Agustus 1945 yang bertujuan untuk melindungi Negara. Kepolisian Negara Indonesia juga memiliki Undang-Undang yang mengatur tugas dan kewajibannya yaitu UndangUndang Nomor Nomor 2 Tahun 2002 tentang Kepolisian.

Kepolisian juga bertugas dan atau memiliki hak dan bahkan kewajiban untuk menangkap para pelanggar dan pembuat kejahatan yang ada di Indonesia. Pelaku kejahatan disebut juga tersangka. Tersangka yaitu seseorang yang perbuatannya atau keadaannya karena, berdasarkan bukti permulaan juga dapat diduga sebagai pelaku tindak pidana. Seseorang juga bisa akan tidak lagi menyandang statusnya sebagai tersangka, jika terhadap perkaranya yang dilakukan penghentian penyidikan.

Di Negara Republik Indonesia Kepolisian Daerah (Polda) yaitu merupakan pelaksana utama Kewilayahan yang berada di bawah Kapolri. Polda yang bertugas menyelenggarakan tugas Polri di suatu tingkat wilayah. Polda dipimpin oleh Kepala Kepolisian Negara Republik Indonesia Daerah (Kapolda), yang bertanggung jawab kepada Kapolri. Kapolda dapat dibantu oleh Wakil Kapolda (Wakapolda). Kepolisian di Negara Republik Indonesia (Polri) yaitu Kepolisian Nasional di Indonesia, mampu bertanggung jawab langsung di bawah Presiden. Polri mengemban tugas-tugas kepolisian yang mencakup seluruh wilayah Indonesia. Polri dipimpin dengan seorang Kepala Kepolisian Negara Republik Indonesia (Kapolri). Saat ini Kapolri dijabat oleh Jenderal Polisi Tito Karnavian, mulai bertugas pada tanggal 13 Juli 2016. Organisasi Polri disusun secara berjenjang dari tingkat pusat sampai ke kewilayahan. Organisasi Polri Tingkat Pusat dapat disebut Markas Besar Kepolisian Negara Republik Indonesia (Mabes Polri); sedang organisasi Polri Tingkat Kewilayahan disebut Kepolisian Negara Republik Indonesia Daerah (Polda). Struktur kepemimpinan Mabes Polri yaitu Kepala Kepolisian Negara Republik Indonesia (Kapolri). Kapolri merupakan kepemimpinan Polri yang bertugas dan bertanggung jawab menurut instruksi Presiden.

Penangkapan yaitu suatu perbuatan penyidik merupakan pengekangan kebebasan tersangka untuk sementara waktu dan terdakwa apabila terdapat cukup bukti untuk kepentingan penyidikan serta penuntutan atau peradilan dengan ketentuan yang berlaku dalam UU. Setiap orang yang dapat melakukan penangkapan jika pelaku kejahatan tertangkap tangan. Penangkapan Tersangka tentu saja memiliki syarat penangkapan yaitu :

1. Penangkapan wajib didasarkan pada bukti permulaan yang cukup

2. Melakukan penangkapan tidak sewenang-wenang 
3. Berpijak pada landasan hukum

4. Tidak menggunakan kekerasan

Pengertian mengenai istilah salah tangkap tidak terdapat dalam KUHAP maupun dalam peraturan perundang-undangan lainnya. Pengertian dari salah tangkap hanya dapat ditemukan tindakan penangkapan yang terjadi akibat kekeliruan terhadap orang yang ditangkap. Tindakan salah tangkap atau kekeliruan mengenai orangnya dimungkinkan terjadi oleh karena penyidik tidak memiliki bukti yang cukup kuat untuk menangkap seseorang atau pelaku yang diduga sebagai pelaku tindak pidana sehingga menyebabkan error in persona.

Kekeliruan dalam penangkapan orang yang ditangkapatau ditahan karena terdapat kekeliruan, sedangkan seseorang yang ditangkap tersebut telahmenjelaskan bahwa dirinya bukan yang dimaksud hendak ditangkap dan ditahan. Penjelasan berdasarkan di atas dapat dimengerti bahwa berbagaimacam istilah terdapat atau penyebutan terhadap kondisi atau keadaan dimana penegakhukum dapat melakukan kesalahan dan kekeliruan karena saat melakukan penangkapan,penahanan, penuntutan atau pemeriksaan di pengadilan.

Kejadian salah tangkap yaitu bukti buruknya kinerja hukum yang ada di negara ini, salah tangkap merupakan tindakan non profesional yang tidak menjalankan aturan dan prinsip yang seharusnya dijalankan oleh kepolisian, dari mulai mendeteksi kejahatan, identiikasi korban harus secara jelas sesuai prosedur yang berlaku agar tidak ada kejadian yang dapat merugikan dan membuat keresahan keluarga terduga tersangka. Barang bukti, olah tkp dan cara kerja aparatur yang memeriksa dan menyelidiki kejadian seharusnya tidak mendukung pihak manapun agar dapat menyelidiki dengan netral tanpa mengenal dan berpihak dengan pihak manapun.

Kejadian salah tangkap lebih banyak diawali dengan fakta yang diyakini untuk menimbulkan kesan seolah-olah publik percaya pada pelakunya memberikan kesan tercapainya aparatur hukum yaitu pihak kepolisian dalam memecahkan sebuah kasus atau kejadian. Intimidasi atau adanya rekayasa dalam keterangan berita acara pemeriksaan merupakan salah satu alasan mengapa seseorang dipaksa mengakui hal yang tidak dilakukannya. Lebih banyak berita yang beredar dengan adanya penyiksaan dan pemaksaaan agar orang yang masih diduga tersangka menjadi seorang tersangka karena pengakuannya dan akibat adanya paksaan.

\section{Upaya Hukum yang Ditempuh Tersangka Jika Terjadi Salah Tangkap}

Salah tangkap merupakan istilah yang tidak ada di KUHP maupun peraturan perundang- undangan yang lain. Salah tangkap tersangka merupakan kekeliruan dalam penangkapan orang yang disangka sebagai pelaku pelanggaran undang-undang atau aturan yang ada (Sebayang, 2019).Akibatnya upaya hukum dalam kasus ini harusnya tidak berada di pihak korban yang menjadi korban salah tangkap namun seharusnya untuk memenuhi rasa keadilan dalam bermasyarakat yang seharusnya harus menjadi tanggungjawab dari aparat berwenang (penyidik kepolisian). Penangkapan yaitu sesuatu kewenangan yang diberikan oleh undang-undang kepada penyidik agar bisa menangkap seseorang yang terduga telah melaksanakan tindak pidana. Dari ketentuan ayat (1) Pasal 18 Kitab Undang-Undang Hukum Pidana jelas tertera bahwa dalam melakukan penangkapan Penyidik harus:

1. Menunjukkan surat tugas kepada tersangka bahwa ia ditugaskan untukmelakukan penangkapan.

2. Memberikan surat perintah penangkapan kepada tersangka yang memuat :

a) Identitas atau nama tersangka yang hendak ditangkap.

b) Menyebutkan alasan penangkapan, kenapa tersangka ditangkap.

c) Uraian singkat tentang perkara kejahatan yang diduga dilakukan tersangka.

d) Menyebutkan tempat tersangka akan diperiksa, misalnya di Polres Jakarta Pusat atau di Polda Metro Jaya atau Bareskrim Mabes Polri.

Akibatnya hukum kasus salah tangkap tersebut harusnya tidak hanya pihak korban yang menjadi korban salah tangkap namun pada seharusnya demi memenuhi rasa keadilan dalam masyarakat yang semestinya juga menjadi tanggungjawab dari penyidik kepolisian. Penyidik juga tak berkewajiban untuk menyatakan penyesalannya ataupun meminta maaf secara tertutup dan secara terbuka. Tersangka juga memiliki hak, beberapa hak tersangka adalah sebagai berikut:

1. Hak dapat diperiksa, diajukan ke pengadilan,dan diadili

2. Hak agar dapat memberikan keterangan kepada hakim dan penyidik

3. Hak agar mendapat bantuan hukum dari Advoka 
4. Hak agar mendapat juru bahasa

5. Hak menghubungi dokter untuk tersangka yang di tahan

6. Hak untuk dapat diberitahukan kepada keluarga

Namun kebanyakan hak-hak tersangka tidak diindahkan, dan tidak dianggap perlu untuk menyampaikan hak-hak mereka. Sekalipun tersangka tetap saja merupakan manusia yang memiliki hak asasi manusia. Namun kebanyakan orang menganggap sesuai kejadian yang dilakukan oleh tersangka yang dilakukan tidak manusiawi sehingga sang pelaku secara social dihukum oleh masyarakat dengan harus menanggung malu. Selain tersangka yang mendapatkan sanksi sosial, keluarga dari tersangka juga mendapatkan sanksi sosial nya , karena masyarakat akan menjauhi dan membuat malu keluarga tersangka.

Bentuk formal pada perilaku kejahatan yaitu peradilan pidana. Namun, akan tetapi bukan berarti reaksi yang dilakukan dengan cara ceroboh tanpa adanya perlindungan terhadap HAM. Mulai dari hak agar disangka tidak bersalah, hak agar dapatkan bantuan hukum, hak agar tidak disiksa, dan beberapa hak lainnya ketika seseorang dinyatakan bersalah.

Kewajiban sistem sistem peradilan pidana dalam hal ini agar melakukan pemeriksaan secara profesional, lebih mengedepankan fakta atau bukti yang kuat untuk menyatakan seseorang itu bersalah atas suatu kejahatan, tujuan pidana itu sendiri dan hak-hak seharusnya diterima oleh terpidana untuk melaksanakan pemidanaan sesuai dengan tujuan pidana. Keharusan ini mutlak adanya mengingat instrumentasi hukum sangat menitikberatkan pada kewenangan-wenangan lembaga penegak hukum dibandingkan dengan posisi tersangka, terdakwa, serta terpidana.

Suatu tindak pidana terjadi apabila, lembaga yang pertama berhadapan langsung di masyarakat yaitu Kepolisian, baik yang dimaksud sebagai korban, atau saksi, serta tersangka. Oleh karena itu, bahwa lembaga kepolisian memiliki tugas terutama agar melindungi keamanan dalam negara serta menjadi penegak hukum utama yang dalam tugas seperti biasa bisa saja juga mendapat omongan yang tidak diinginkan, tidak dihormati, serta tidak akan di percayai oleh masyarakat.

Kejadian salah tangkap inilah yang mengakibatkan banyaknya pihak kepolisian dan departemen kepolisian yang tidak dipercaya oleh masyarakat, masyarakat lebih memilih untuk main hakim sendiri daripada melaporkan kepihak kepolisian karena tidak mempercayai kinerja kepolisian. Seharusnya pihak kepolisian menyadari dan memperketat tata cara penyelidikan agar tidak terjadi kejadian salah tangkap, banyak pihak yang dirugikan dengan kesalahan yang terjadi seperti kasus salah tangkap ini.

Dalam kasus pidana sebenarnya yang dicari adalah kebenaran materiil, seseorang tidak dapat dipidana hanya dengan pengakuan verbal tanpa ada pembuktian . Korban salah tangkap itu sendiri berhak untuk mendapatkan pemulihan dalam pembersihan nama baik dan hal lainnya yang dapat membantu dia dalam memulihkan keadaan dirinya.

Dalam buku Perundang-undangan Hukum Acara Pidana (KUHAP) pasal 1 ayat 20 sudah dijelaskan bahwa: "penangkapan adalah suatu tindakan penyidik berupa pengekangan sementara waktu kebebasan tersangka atau terdakwa apabila terdapat cukup bukti guna kepentingan penyidikan atau penuntutan dan atau peradilan dalam hal ini serta menurut cara yang diatur dalam undangundang ini”. Pasal 17 menunjukan alasan mengenai penangkapan atau syarat penangkapan yaitu sebagai berikut :

a) Tindakan pidana, seorang tersangka diduga keras melakukan tindakan pidana,

b) Dan dugaan yang kuat itu didasarkan pada bukti permulaan yang cukup.

Yang menunjukan pasal ini agar perintah penangkapan tidak dapat dilakukan dengan sewenangwenang, tetapi dapat ditujukan kepada mereka yang betul-betul melakukan tindak pidana. proses penangkapan mempunyai konsekuensi kesalahan yang cukup besar dikarena kekeliruan tersebut tidak segera diperbaiki maka dari itu kekeliruan tersebut terus berlangsung pada tahap-tahap berikutnya.

Upaya hukum tentang pertanggungjawaban Penyidik Polri jika terjadi salah tangkap saat menjalankan tugas dan upaya hukum yang dapat dilakukan tersangka jika terjadi salah tangkap karena Penyidik Polri. Pertama, bentuk-bentuk sanksi yang terdapat dalam Kode Etik Profesi Kepolisian Negara Republik Indonesia pelanggaran yang dilakukan yaitu sebagai berikut;

1. Perilaku pelanggaran dinyatakan sebagai perbuatan tercela

2. Kewajiban pelanggar untuk meminta maaf secara terbatas ataupun secara langsung 
3. Kewajiban pelanggar untuk mengikuti pembinaan ulang profesi

4. Pelanggar dinyatakan tidak layak lagi untuk menjalankan fungsi Kepolisian,

Menurut Pasal 1 Ayat 22 KUHAP upaya hukum yang dapat di laksanakan yaitu, ganti kerugian. Yang menjadi dasar hukum untuk tuntutan ganti kerugian adalah Pasal 77 poin b KUHAP, kemudian rehabilitasi yang sesuai dengan Pasal 1 Ayat 10 KUHAP c). Dari penelitian ini dapat disimpulkan bahwa bentuk tanggung jawab yang dilakukan oleh penyidik Polri dibedakan menjadi 2 yaitu tanggung jawab materiil, yaitu mengenai sanksi pernyataan maaf serta tanggung jawab imateriil yakni mengenai sanksi berupa kewajiban pembinaan ulang di lembaga pendidikan Polri. Sedangkan upaya hukum yang dilakukan oleh korban salah tangkap yaitu dengan melakukan tuntutan ganti rugi dan rehabilitasi.

\section{SIMPULAN DAN SARAN}

\section{Simpulan}

Salah tangkap dapat terjadi karena tindakan nonprofesional aparat kepolisian dalam menjalankan prinsip-prinsip kriminalisasi, mulai dari mendeteksi kejahatan, identifikasi korban, tersangka dan korelasinya secara ilmiah dengan kata lain terjadi kesalahan dalam Scientific Crime Investigation (penyidikan kejahatan secara ilmiah). Kedua, kebanyakan kasus salah tangkap diawali dengan fakta yang dipolitisir untuk dapat menimbulkan kesan seolah-olah publik percaya pada pelakunya, atau memberikan kesan telah adanya upaya hukum yang dicapai oleh aparat hukum. Ketiga salah tangkap merupakan penjabaran yang salah dari prinsip-prinsip dasar manajemen, dengan tidak memperhatikan profesionalitas dalam pengambilan penemuan alat bukti.

\section{Saran}

Dalam hal ini saran yang diberikan seharusnya Kepolisian harus teliti sehingga hasil dalam penyelidikan itu lebih matang dan dapat meminimalisir terjadinya akan salah tangkap, selain itu penyidik lebih dapat berhati-hati dalam penyelidikan atau mencari data. Untuk mencegah dalam menanggulangi terjadinya salah tangkap maka upaya Direktur Reserse Kriminal Umum melaksanakan bimbingan secara teknik pada tingkat Polda atau Polres dangan secara langsung maupun secara tertulis dengan menggunakan telegram atau juklak.

Perlunya upaya hukum yang bisa dilakukan oleh seseorang tersangka yang ternyata merupakan korban yang terjadi salah tangkap, maka ia dapat mengajukan upaya hukum berupa upaya pra peradilan. Dalam praktek dilapangan sebaiknya tersangka dipermudah dengan mengajukan upaya hukum tersebut.

\section{DAFTAR PUSTAKA}

Dyani, V. A. (2017). Pertanggungjawaban Hukum dan Perlindungan Hukum bagi Notaris dalam Membuat Party Acte. Jurnal Lex Renaissance, 2(1), 162-176.

Harahap, M. Y. (2006). Pembahasan Permasalahan dan Penerapan KUHAP: Penyidikan dan Penuntutan O.C.Kaligis. Alumni Bandung.

Lathif, N. (2018). Pertanggungjawaban Pidana Penyidik POLRI dalam Kasus Salah Tangkap. 4(2), 358-404.

Sebayang, S. (2019). Praperadilan Sebagai Salah Satu Upaya Perlindungan Hak-Hak Tersangka Dalam Pemeriksaan Di Tingkat Penyidikan (Studi Pengadilan Negeri Medan). Jurnal Hukum Kaidah: Media Komunikasi Dan Informasi Hukum Dan Masyarakat, 19(2), 114-136.

Sudiro, A. (2012). Konsep Keadilan dan Sistem Tanggung Jawab Keperdataan dalam Hukum Udara. Jurnal Hukum Ius Quia Iustum, 19(3), 439-454.

Sudjana, S. (2019). Akibat Hukum Wanprestasi dan Tanggung Jawab Para Pihak dalam Transaksi Anjak Piutang. Veritas et Justitia, 5(2), 374-398.

Tetepa, B. (2013). Pertanggungjawaban Penyidik Polri dan Upaya Hukum Tersangka Atas Terjadinya Salah Tangkap. Journal of Lex Crimen, 2(7), 1689-1699.

Undang-Undang Republik Indonesia Nomor 2 Tahun 2002 Tentang Kepolisian Negara Republik Indonesia.

Undang-Undang Republik Indonesia Nomor 2 Tahun 2002 Tentang Kepolisian Negara Republik Indonesia 